\begin{tabular}{|c|c|c|c|c|}
\hline Share: Social Work Jurnal & VOLUME: 10 & NOMOR: 1 & HALAMAN: 40-50 & $\begin{array}{c}\text { ISSN: 2339-0042 (p) } \\
\text { ISSN: 2528-1577 }(e) \\
\text { DOI: 10.24198/share.v10i1.26529 }\end{array}$ \\
\hline
\end{tabular}

\title{
STRENGTHS-PERSPECTIVE DALAM PENGEMBANGAN KEBIJAKAN SOSIAL
}

\author{
Marcelino Vincentius Poluakan ${ }^{1}$, Nandang Mulyana², Hadiyanto A. Rachim ${ }^{3}$ \\ ${ }^{1}$ Program Magister IImu Kesejahteraan Sosial, FISIP, Universitas Padjadjaran \\ ${ }^{2}$ Pusat Studi CSR, Kewirausahaan Sosial dan Pemberdayaan Masyarakat, FISIP - Universitas \\ Padjadjaran
}

marcelinopoluakan86@gmail.com

\begin{abstract}
ABSTRAK
Strengths-Perspective sebagai pendekatan dalam pekerjaan sosial telah mulai digunakan dalam pengembangan kebijakan sosial. Penggunaan pendekatan ini sejalan dengan cita-cita yang ingin dicapai dalam intervensi pekerjaan sosial yaitu untuk mewujudkan self-determination serta keadilan sosial dalam sebuah kebijakan sosial. Oleh karena itu, setiap kebijakan sosial yang disusun seharusnya memuat nilai-nilai di atas. Tulisan ini akan membahas pentingnya Strengths-Perspective dalam pengembangan kebijakan sosial, apa manfaatnya serta bagaimana kerangkanya. Tulisan ini akan menggunakan studi literatur berupa buku, artikel, dan sumber lain yang kredibel serta relevan dengan topik yang dibahas. Hasil kajian menunjukkan Strengths-Perspective sangat dibutuhkan dalam pengembangan sebuah kebijakan sosial. Strengths-Perspective dapat menjadi pendekatan yang memperkaya dan memperkuat sebuah kebijakan sosial sehingga dapat menjawab masalah sosial dengan lebih efektif. Dengan demikian, kebijakan yang dihasilkan juga akan memberikan nilai tambah bagi setiap sasarannya seperti kemandirian, ketahanan, keberdayaan, keterlibatan, dan sebagainya. Walaupun terdapat tantangan sebagai sebuah pendekatan yang baru, StrengthsPerspective dapat terus kita upayakan dalam pengembangan kebijakan sosial.
\end{abstract}

Kata kunci: Strengths-Perspective, kebijakan sosial, pengembangan kebijakan sosial

\begin{abstract}
Strengths-Perspective as an approach in social work has begun to be used in the development of social policy. The use of this approach is in line with the values to be achieved in social work interventions, namely self-determination and social justice in a social policy. Therefore, every social policy formulated should contain the values above. This paper will discuss the importance of Strengths-Perspective $s$ in the development of social policies, the benefits and the framework. This paper will use literature studies in the form of books, articles, and other sources that are relevant to the topics discussed. The results of the study show that Strengths-Perspective is very much needed in the development of social policy. Strengths-Perspective can be an approach that enriches and strengthens social policy so that it can answer social problems more effectively. Thus, the resulting policy will bring about values to each of its targets such as self-determination, resilience, empowerment, involvement, and so on. Although there are challenges as a new approach, we can continue to work on Strengths-Perspective in developing social policies.
\end{abstract}

Keywords: Strengths-Perspective, social policy, social policy development 


\section{PENDAHULUAN}

Strengths-Perspective merupakan salah satu pendekatan dalam pekerjaan sosial. Perspektif ini memandang bahwa individu, keluarga maupun komunitasnya memiliki potensi dan kekuatan yang dapat didayagunakan untuk mengatasi permasalahan yang mereka hadapi. Setiap individu mempunyai sumber daya dan kapasitas untuk mengembangkan kehidupan mereka yang belum dimanfaatkan (Ishartono, 2016). Fokus dari perspektif ini adalah kekuatan sebagai sumber pertolongan serta solusi dan bukan pada permasalahan yang dihadapi oleh individu maupun komunitasnya. Bukan berarti menyepelekan masalah yang secara nyata terjadi, tetapi melangkah lebih jauh mencari solusinya melalui kekuatan yang dimiliki oleh para penyandang masalah tersebut.

Pada awal perkembangannya, pendekatan Strengths-Perspective digunakan dalam intervensi pekerjaan sosial klinis misalnya terhadap individu atau keluarga (Guo, et.al, 2010). Pada tahun 1995, Chapin memperkenalkan pendekatan ini dalam pengembangan kebijakan sosial (Rapp, et. all, 2006). Seiring dengan itu, beberapa praktisi pekerjaan sosial mulai menyusun prinsipprinsip maupun indikator bagi sebuah kebijakan sosial yang Strengths-Based seperti Rapp, Pettus, Goscha (2006) dan Hill (2008) serta mulai menggunakannya dalam menganalisis dan mengembangkan berbagai bentuk kebijakan sosial.

Penggunaan pendekatan ini dalam pengembangan kebijakan sosial juga tidak terlepas dari praktik pekerjaan sosial pada level makro. Praktik pada level ini sering didefinisikan sebagai intervensi yang didesain untuk menghasilkan perubahan dalam ruang lingkup organisasi, komunitas dan kebijakan (Netting, et.al., 2017). Intervensi pada level makro didasari bahwa pekerjaan sosial maupun para pekerja sosial menyadari bagaimana lingkungan sekitar sering menjadi faktor yang mempengaruhi individu, keluarga serta kelompok atau komunitas. Dengan kata lain, terkadang lingkunganlah yang perlu diubah bukan individunya (Netting, et.al., 2017). Mullaly (dalam Netting et.al., 2017) menyatakan bahwa pekerja sosial tidak hanya dipanggil untuk menjadi praktisi langsung, tetapi juga untuk menjadi agen perubahan terutama dalam situasi untuk memperjuangkan kepentingan penerima layanan.

Pada level tersebut, intervensi berfokus pada kondisi dan kebijakan sosial, politik dan ekonomi yang mempengaruhi akses masyarakat kepada sumber-sumber daya serta peningkatan kualitas hidup. Praktik pekerjaan sosial di level makro melibatkan upaya-upaya untuk meningkatkan bidangbidang sosial dan ekonomi dimana masyarakat hidup (Zastrow, et.al., 2007). Pekerjaan sosial dapat terlibat dalam sebuah upaya "advokasi sosial" yaitu dalam proses pengembangan kebijakan sosial mulai dari tahap agenda setting, formulasi, implementasi, evaluasi dan perbaikan kebijakan sehingga kebijakan yang dihasilkan dapat memberdayakan (Brueggemann, 2014).

Praktik makro dengan sasaran kebijakan sosial ini tidak terlepas dari perhatian terhadap kebijakan sosial agar lebih efektif dalam menyelesaikan permasalahan sosial. Kebijakan sosial dibuat untuk menghasilkan sebuah perubahan (Nugroho, 2014). Bila perubahan sebagai hasil dari implementasi kebijakan sosial belum nampak, maka dibutuhkan upaya yang lebih efektif dalam menghasilkan perubahan. Salah satu aspek yang perlu mendapat perhatian adalah metode analisis dan formulasi kebijakan sosial yang selama ini biasanya berfokus pada permasalahan atau berorientasi pada patologis. Kebijakan sosial sering dipandang sebagai tanggapan atau jawaban langsung terhadap masalah sosial (Chapin, 1995).

Pekerjaan sosial sendiri dalam praktiknya memiliki misi sebagaimana digariskan dalam Kode Etik yang dikembangkan oleh Nasional Association of Social Workers (NASW). Misi tersebut terwujud dalam nilai-nilai yang menjadi pedoman dalam praktik pekerjaan sosial yang 
dalam konteks ini berarti membentuk suatu kebijakan sosial yang lebih efektif. Nilai-nilai tersebut adalah determinasi diri dan keadilan sosial (Chapin, 2011). Nilai-nilai ini juga yang melalui Strengths-Perspective akan coba diintegrasikan dalam pengembangan kebijakan sosial.

Tulisan ini akan menggambarkan sejauh mana Strengths-Perspective dapat menjadi salah satu pendekatan dalam pengembangan kebijakan sosial. Tulisan ini akan menggali mengapa harus StrengthsPerspective serta apa manfaat dan kelebihan yang dimilikinya. Penulis juga akan membahas apa kekhasan dan kerangka yang dimiliki oleh Strengths-Perspective sehingga pendekatan ini dapat digunakan untuk membantu dan memperkuat pengembangan kebijakan sosial sehingga menjadi lebih efektif dan tepat sasaran.

Penulis akan melandaskan konsep pada literatur-literatur tentang StrengthsPerspective dalam pengembangan kebijakan sosial. Harus diakui bahwa kajian maupun literatur tentang Strengths-Perspective dalam hubungannya dengan pengembangan kebijakan sosial tidaklah banyak. Hal ini dapat dimaklumi karena Strengths-Perspective dalam perkembangan awalnya sering digunakan dalam intervensi pekerjaan sosial mikro ataupun pekerjaan sosial klinis seperti intervensi terhadap individu dan keluarga. Tulisan ini menjadi sebuah upaya untuk memperkenalkan Strengths-Perspective dalam pengembangan kebijakan sosial.

\section{METODE}

Tulisan ini merupakan kajian ataupun studi terhadap literatur-literatur yang membahas Strengths-Perspective dalam pengembangan sebuah kebijakan sosial. Penulis akan melandaskan kajian ini pada konsep-konsep dan prinsip-prinsip tentang Strengths-Perspective serta pengembangan kebijakan sosial. Sumber-sumber yang digunakan untuk mendukung konsep ini adalah buku, artikel serta sumber lain yang relevan serta kredibel terutama dalam mendukung konsep yang diangkat penulis yaitu Strengths-Perspective

dalam pengembangan kebijakan sosial.

Penulis menyadari bahwa sumber atau literatur tentang Strengths-Perspective dalam pengembangan kebijakan sosial belum begitu banyak. Sejauh ini, Strengths-Perspective umum digunakan dalam intervensi pekerjaan sosial terhadap individu, keluarga maupun komunitas (Rapp et al., 2006). Beberapa akademisi serta praktisi pekerjaan sosial dari luar negeri telah mencoba mengembangkan kerangka konseptual pendekatan ini dalam sebuah kebijakan sosial. Untuk membantu memudahkan kita dalam memahami pendekatan ini dalam kebijakan sosial, penulis akan menggunakan konsep pelayanan sosial sebagai salah satu representasi dari kebijakan sosial (Spicker, 2014).

\section{TINJAUAN KONSEPTUAL}

\section{Strengths-Perspective}

Strengths-Perspective atau perspektif berbasis kekuatan merupakan pendekatan dalam pekerjaan sosial yang pertama kali diperkenalkan oleh Dennis Saleebey (Guo, et. all, 2010). Saleebey (dalam Chapin, 2011) mendefinisikan Strengths-Perspective sebagai sebuah pendekatan filosofis bagi pekerjaan sosial yang menempatkan tujuan, kekuatan dan sumber-sumber dalam diri manusia dan lingkungan sekitarnya sebagai fokus utama dalam proses pertolongan, dan bukan pada permasalahan atau patologi. Pendekatan ini berakar pada keyakinan bahwa setiap orang dapat terus bertumbuh dan berubah serta harus memiliki akses yang sama terhadap berbagai sumber daya (Chapin, 1995). Pendekatan ini mengharuskan juga kita untuk memahami bahwa setiap orang tanpa terkecuali memiliki aset, kompetensi dan sumber daya internal dan eksternal (Saleebey, 2000).

Kemunculan dari StrengthsPerspective khususnya dalam pekerjaan sosial dipandang sebagai paradigma baru terhadap perspektif yang Problem-Based atau sering disebut juga Problem-Centered atau Pathology-Oriented. Sebagaimana ditunjukkan dalam tabel 1 , kedua perspektif di 


\begin{tabular}{|c|c|c|c|c|}
\hline Share: Social Work Jurnal & VOLUME: 10 & NOMOR: 1 & HALAMAN: $40-50$ & $\begin{array}{c}\text { ISSN: 2339-0042 (p) } \\
\text { ISSN: 2528-1577 (e) } \\
\text { DOI: 10.24198/share.v10i1.26529 }\end{array}$ \\
\hline
\end{tabular}

atas memiliki perbedaan yang cukup signifikan. Bagi Saleebey, praktik pekerjaan sosial tidak serta merta menghilangkan atau mengabaikan perspektif Problem-Based. Permasalahan merupakan suatu hal yang riil dan harus diakui. Namun, pekerjaan sosial tidak berhenti sampai pada permasalahan, tapi dituntut untuk memahaminya dengan cara yang berbeda. Semuanya dipahami dalam terang akan kapasitas, talenta, kompetensi, kemungkinan, visi, nilai dan harapan (Saleebey, 1995).

Tabel 1. Perbandingan antara Perspektif Patologi dan Kekuatan

\begin{tabular}{|l|l|}
\hline \multicolumn{1}{|c|}{ Patologi } & \multicolumn{1}{c|}{ Kekuatan } \\
\hline $\begin{array}{l}\text { Individu dipandang sebagai sebuah "kasus" } \\
\text { dengan berbagai gejalanya }\end{array}$ & $\begin{array}{l}\text { Individu dipandang sebagai sesuatu yang unik } \\
\text { dengan kekuatan yang dimilikinya seperti sifat- } \\
\text { sifat, talenta, serta sumber daya }\end{array}$ \\
\hline Terapi berfokus pada permasalahan & Terapi berfokus pada kemungkinan \\
\hline $\begin{array}{l}\text { Akun-akun pribadi menentukan kemunculan } \\
\text { diagnosa melalui reinterpretasi dari seorang ahli }\end{array}$ & $\begin{array}{l}\text { Akun-akun pribadi adalah langkah penting untuk } \\
\text { memahami dan mengapresiasi individu }\end{array}$ \\
\hline $\begin{array}{l}\text { Praktisi bersikap skeptis dengan cerita pribadi, } \\
\text { berupaya merasionalisasi }\end{array}$ & $\begin{array}{l}\text { Praktisi berusaha memahami individu secara } \\
\text { mendalam }\end{array}$ \\
\hline $\begin{array}{l}\text { Trauma masa kecil adalah prekursor atau } \\
\text { prediktor bagi patologi orang dewasa }\end{array}$ & $\begin{array}{l}\text { Trauma masa kecil tidak dapat diprediksi; dapat } \\
\text { melemahkan atau memperkuat individu }\end{array}$ \\
\hline Terapi dirancang oleh praktisi & $\begin{array}{l}\text { Terapi merupakan aspirasi dari keluarga, individu } \\
\text { atau komunitas }\end{array}$ \\
\hline Praktisi dianggap sebagai ahli bagi kliennya & $\begin{array}{l}\text { Individu, keluarga dan komunitas menjadi ahli } \\
\text { bagi kliennya }\end{array}$ \\
\hline $\begin{array}{l}\text { Berbagai kemungkinan atas pilihan, kontrol, } \\
\text { komitmen, dan pengembangan pribadi dibatasi } \\
\text { oleh patologi }\end{array}$ & $\begin{array}{l}\text { Berbagai kemungkinan atas pilihan, kontrol, } \\
\text { komitmen, dan pengembangan pribadi terbuka } \\
\text { lebar }\end{array}$ \\
\hline $\begin{array}{l}\text { Sumber daya untuk bekerja adalah pengetahuan } \\
\text { dan keterampilan dari para profesional }\end{array}$ & $\begin{array}{l}\text { Sumber daya untuk bekerja adalah kekuatan, } \\
\text { kapasitas dan kemampuan adaptif dari individu, } \\
\text { keluarga dan komunitas }\end{array}$ \\
\hline $\begin{array}{l}\text { Bantuan berfokus untuk meminimalisir efek dari } \\
\text { gejala-gejala dan konsekuensi personal dan } \\
\text { sosial yang negatif dari tindakan, emosi, pikiran, } \\
\text { atau relasi }\end{array}$ & $\begin{array}{l}\text { Bantuan berfokus untuk melanjutkan kehidupan, } \\
\text { menguatkan dan mengembangkan nilai-nilai dan } \\
\text { komitmen, dan melibatkan kembali seseorang } \\
\text { dalam komunitasnya }\end{array}$ \\
\hline
\end{tabular}

Sumber: Saleebey, 1995

Berbagai nilai dan kekhasan dari Strengths-Perspective dalam pekerjaan sosial di atas dapat ditarik dalam tiga kata kunci. Bagi Saleebey, kunci yang harus ada dalam sebuah Strengths-Perspective adalah pemberdayaan, resiliensi dan keanggotaan atau keterlibatan (Saleebey, 1995). Tiga konsep kunci di atas harus ada ketika mengimplementasikan pendekatan StrengthsPerspective baik dalam intervensi mikro, mezzo maupun makro.

Pada awalnya, Strengths-Perspective melekat dalam praktik pekerjaan sosal klinis seperti dengan individu maupun keluarga. Praktik Strengths-Based awal teridentifikasi pada manajemen kasus penderita penyakit jiwa berat. Kemudian, berkembang juga praktik Strengths-Based dengan kelompokkelompok seperti orang lanjut usia, orang muda yang bermasalah, orang dengan ketergantungan, dan sebagainya (Saleebey, 1995). Setelah itu, terjadi perubahan dalam profesi pekerjaan sosial yang ditandai dengan pergeseran dan penekanan yang sebelumnya pada intervensi terhadap individu menjadi intervensi dengan dan dalam sistem yang lebih besar (Netting, et.al., 2017).

Dalam perkembangannya, StrengthsPerspective mulai diterapkan dalam analisis dan pengembangan kebijakan sosial. Chapin (1995) mengatakan bahwa StrengthsPerspective dapat digunakan untuk 
memformulasikan kembali pendekatan yang Problem-Focused dan Pathology-Centered dalam pengembangan kebijakan sosial. Sejak itu, beberapa praktisi pekerjaan sosial seperti Rapp, Pettus, Goscha (2006) dan Hill (2008) mencoba menyusun kerangka konseptual sebuah kebijakan sosial yang StrengthsBased. Mereka juga mencoba mengaplikasikan kerangka analisis kebijakan yang Strengths-Based dalam menganalisis kebijakan sosial di Amerika Serikat seperti John $\mathrm{H}$. Chafee Foster Care Independence Act (Hill, 2008). Bagi Chapin, dengan mengaplikasikan gagasan StrengthsPerspective dalam pengembangan kebijakan sosial, akan muncul pendekatan yang lebih inklusif dalam formulasi kebijakan dan memperluas berbagai opsi kebijakan.

\section{Kebijakan Sosial dan Pelayanan Sosial}

Kebijakan merupakan sebuah aksi yang diambil oleh sebuah organisasi untuk menjawab tuntutan seperti peningkatan kompleksitas dan kecepatan dalam organisasi tersebut. Kebijakan biasanya berbentuk tertulis yang memuat pernyataan preskriptif tentang tujuan, pembuatan keputusan dan aktivitas organisasional (Midgley, et. all, 2009). Wujud nyata dari sebuah kebijakan bisa bermacam-macam. Birkland (2011) menyebut bahwa kebijakan bisa berupa hukum, regulasi atau sekumpulan hukum dan regulasi yang mengatur isu atau masalah tertentu. Anne Schneider and Helen Ingram mengatakan bahwa kebijakan terwujud melalui teks-teks, praktik-praktik, simbolsimbol maupun ceramah-ceramah yang membawa nilai-nilai termasuk barang maupun layanan demikian juga regulasi, pendapatan, status, serta atribut-atribut lain yang bernilai positif maupun negatif (Birkland, 2011).

Pemerintahan sebagai sebuah organisasi formal juga mengadopsi kebijakan sebagai program aksinya. Kebijakan menjadi sarana untuk memajukan pengembangan ekonomi, menjaga hukum dan ketertiban, mengatur hubungan dengan negara lain, membela negara dalam menghadapi ancaman-ancaman dari luar, melestarikan lingkungan hidup, menumbuhkan komunikasi, serta mengendalikan pertumbuhan di daerah perkotaan. Pemanfaatan kebijakan sebagai sarana untuk mengatur seperti di atas menjadikannya sebuah kebijakan bersifat publik. Masyarakat umum dapat mengakses kebijakan tersebut serta menjadi bagian dari implementasi kebijakan tersebut. Konteks kebijakan publik menjadi lebih sempit ketika pemerintah mengadopsi kebijakan publik tersebut dalam rangka meningkatkan kesejahteraan warga negaranya. Di sini kita mengenalkan sebagai kebijakan sosial (Midgley, et.al., 2009).

Menurut Suharto (2012), kebijakan sosial adalah seperangkat tindakan (course of action), kerangka kerja (framework), petunjuk (guideline), rencana (plan), peta (map) dan strategi yang dirancang untuk menterjemahkan visi politik pemerintah atau lembaga pemerintah ke dalam program dan tindakan untuk mencapai tujuan tertentu di bidang kesejahteraan sosial. Kesejahteraan sosial menjadi tujuan dari kebijakan sosial. Kebijakan sosial menjadi langkah pemerintah untuk meningkatkan kesejahteraan sosial rakyatnya sehingga pemerintah memunculkan dan mengembangkan suatu kebijakan sosial (Walsh, et. all, 2000).

Selain dalam kaitannya dengan kesejahteraan sosial, kebijakan sosial juga dapat merujuk pada suatu bidang akademik yang membahas berbagai tindakan yang diambil negara yang mempengaruhi kesejahteraan rakyatnya (Spicker, 2014; Walsh, et.al., 2000; Midgley, et.al., 2000). Sebagai suatu bidang akademik, kebijakan sosial mengkaji berbagai visi dan perspektif tentang bagaimana negara dapat mensejahterakan warganya serta dengan cara apa. Kajian tersebut kemudian bisa menjadi input ataupun masukan bagi pemerintah dalam rangka menyusun kebijakan sosial yang lebih efektif dan tepat sasaran.

Kebijakan sosial umumnya muncul karena adanya permasalahan sosial yang harus diselesaikan. Kebijakan sosial bahkan sering diidentikkan sebagai jawaban terhadap permasalahan sosial. Sesuatu dianggap 
sebagai sebuah masalah karena perlu diselesaikan, terlepas dari apakah penyandang masalah tersebut menganggap masalah tersebut adalah sebuah gangguan yang harus diselesaikan atau tidak. Masalah sosial juga terjadi dalam konteks sosial dan bukan dalam konteks pribadi atau individu. Di sini, masalah sosial terkonstruksi secara sosial serta memerlukan penanganan secara sosial (Spicker, 2014).

Ruang lingkup kebijakan sosial sangatlah luas. Oleh karena itu, salah satu perwujudan dari kebijakan sosial adalah pelayanan sosial. Spicker menyebut bahwa pelayanan sosial merupakan salah satu cara di mana kebijakan sosial dapat ditempuh (Spicker, 2014). Pelayanan sosial sendiri memiliki berbagai macam bentuk seperti jaminan sosial, pelayanan perumahan, kesehatan, pendidikan dan pelayanan sosial personal. Semua bentuk pelayanan sosial tersebut dimaksudkan untuk mengatasi masalah-masalah sosial. Masyarakat berharap bahwa pelayanan sosial yang disediakan oleh pemerintah efektif dalam mengatasi persoalan yang dialaminya.

\section{Pengembangan Kebijakan Sosial}

Pengembangan kebijakan sosial
merupakan sebuah proses yang
menerjemahkan gagasan-gagasan kebijakan menjadi sebuah kebijakan yang aktual yang akan diimplementasikan (Birkland, 2011). Dalam proses tersebut, kebijakan sosial melewati berbagai fase atau siklus sehingga gagasan tersebut terwujud menjadi sebuah kebijakan sosial. Proses pengembangan kebijakan sosial juga diharapkan menghasilkan rumusan masalah yang tepat serta kebijakan yang tepat dalam mengatasi masalah tersebut.

Fase-fase dalam pengembangan kebijakan berbeda-beda di antara ahli-ahli kebijakan. Abidin (2016) membagi proses kebijakan publik ke dalam dua bagian besar yaitu perumusan kebijakan publik serta pelaksanaan kebijakan publik. Proses perumusan terdiri dari identifikasi dan perumusan masalah, agenda kebijakan, dan perumusan kebijakan publik sedangkan proses pelaksanaan terdiri dari implementasi kebijakan dan evaluasi kebijakan. Birkland (2011) mengatakan bahwa fase proses pengembangan kebijakan terdiri dari issue emergence, agenda setting, alternative selection, enactment, implementation dan evaluation. Sedangkan, fase kebijakan yang lebih lengkap menurut Dunn (2018) adalah agenda setting, policy formulation, policy adoption, policy implementation, policy assessment, policy adaptation, policy succession, dan policy termination.

$\begin{array}{ccr}\text { Fase-fase } & \text { dalam } & \text { proses } \\ \text { pengembangan } & \text { kebijakan di atas }\end{array}$
menunjukkan bahwa sebuah kebijakan melewati proses yang tidak singkat dan tidak mudah. Setiap fase membutuhkan ketelitian dan kedalaman sehingga hasil akhirnya adalah sebuah kebijakan yang tepat dan efektif untuk diimplementasikan serta membawa hasil yang maksimal. Dalam tulisan ini, penulis tidak akan membahas fase-fase dalam proses kebijakan sosial tersebut. Penulis hanya akan memberikan dasar-dasar untuk memahami sejauh mana prinsip-prinsip StrengthsPerspective termuat dalam keseluruhan proses pengembangan kebijakan sosial tersebut serta secara lebih nyata dalam komponen-komponen yang dimiliki oleh setiap bentuk layanan sosial.

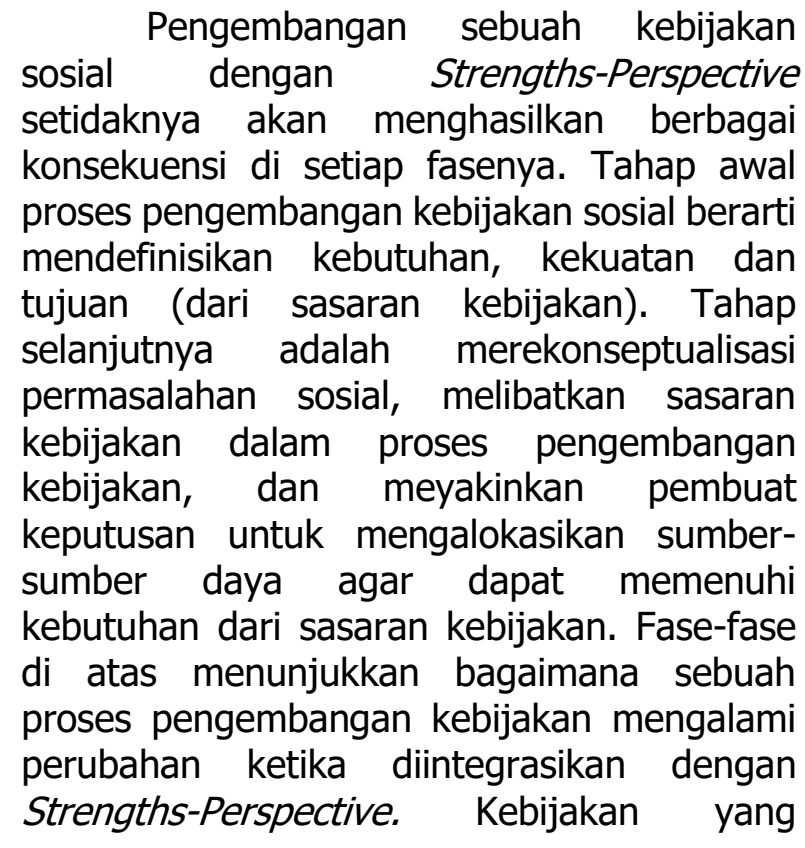
sosial dengan Strengths-Perspective setidaknya akan menghasilkan berbagai konsekuensi di setiap fasenya. Tahap awal proses pengembangan kebijakan sosial berarti mendefinisikan kebutuhan, kekuatan dan tujuan (dari sasaran kebijakan). Tahap selanjutnya adalah merekonseptualisasi permasalahan sosial, melibatkan sasaran kebijakan dalam proses pengembangan kebijakan, dan meyakinkan pembuat keputusan untuk mengalokasikan sumbersumber daya agar dapat memenuhi di atas menunjukkan bagaimana sebuah proses pengembangan kebijakan mengalami Strengths-Perspective. Kebijakan yang 
dihasilkan juga kemungkinan mengalami perubahan (Chapin, 2011).

\section{PEMBAHASAN}

\section{Pelayanan Sosial yang Strengths- Based}

Dalam rangka pengembangan sebuah kebijakan sosial dengan StrengthsPerspective, dibutuhkan prinsip-prinsip sebagai pedoman. Pedoman tersebut dapat digunakan dalam proses pengembangan sebuah kebijakan sosial mulai dari identifikasi masalah, agenda setting, penetapan kebijakan, implementasi kebijakan serta evaluasi kebijakan. Pedoman tersebut juga dapat membantu praktisi kebijakan untuk menganalisis sebuah kebijakan sosial guna memperoleh informasi sejauh mana sebuah kebijakan sosial telah memuat StrengthsPerspective di dalamnya. Kebijakan sosial yang Strengths-Based memunculkan masingmasing prinsip tersebut sambil menunjukkan konsistensi dan kongruensi internal di seluruh kebijakan (Rapp, et.al., 2006).

Rapp, Pettus, dan Goscha (Rapp et. al., 2006) menggagas enam prinsip kebijakan sosial yang strengths-based sebagai berikut:

1. Kebijakan sosial yang strengths-based sejalan dengan pengalaman atau agenda dari sasarannya;

2. Kebijakan sosial yang strengths-based menempatkan masalah pada tempatnya;

3. Kebijakan sosial yang strengths-based menekankan persamaan dan persepsi yang positif terhadap lingkungan;

4. Kebijakan sosial yang strengths-based bersifat sukarela bagi sasarannya;

5. Kebijakan sosial yang strengths-based menekankan pada pilihan; dan

6. Kebijakan sosial yang strengths-based memberikan insentif kesejahteraan yang terstruktur bagi sasarannya.

Bila kita mengintegrasikan prinsipprinsip di atas dalam sebuah pelayanan sosial, maka beberapa indikator yang setidaknya dapat kita temukan antara lain:
1. Pelayanan sosial dirumuskan secara terbuka dan melibatkan siapa saja yang menjadi sasarannya. Pelibatan ini akan menciptakan hubungan emosional sehingga pelayanan sosial yang diberikan benar-benar dapat membantu sasarannya;

2. Adanya pernyataan tujuan dari layanan sosial secara jelas dan terukur serta pernyataan masalah sosial yang dipandang sebagai penghambat dalam mencapai tujuan. Oleh karena itu, identifikasi masalah harus dilengkapi dengan identifikasi tujuan, kebutuhan, harapan, serta hambatan dari sasaran layanan sosial. Penyandang masalah tidak dipandang sebagai masalah dan tidak dilihat apa yang salah dari mereka;

3. Manfaat atau benefit yang diberikan oleh layanan sosial harus sesuai dengan apa yang dibutuhkan oleh target atau sasarannya. Tujuan layanan sosial sejalan dengan pengalaman dari sasarannya serta memahami keragaman persepsi dari sasarannya tentang masalah yang mereka hadapi dan tidak menciptakan persepsi tunggal untuk diaplikasikan kepada setiap sasaran;

4. Pelayanan sosial harus bersifat sukarela bagi setiap sasarannya dan menghormati hak mereka untuk memilih layanan yang mereka butuhkan. Layanan yang tersedia tidak boleh memaksa namun menciptakan ruang serta peluang bagi sasarannya untuk menggunakan kekuatan, bakat, dan keterampilan mereka untuk memenuhi tujuan yang diinginkan;

5. Layanan sosial menekankan keanggotaan yang setara namun tetap berdasarkan prinsip kepantasan (eligilibity) dan menekankan pada persepsi yang positif terhadap lingkungan. Sumber daya komunitas yang telah ada dan "alami" harus dimanfaatkan untuk mengatasi masalah mereka serta tidak menciptakan sumber-sumber baru yang tersegregasi.

6. Layanan sosial bersifat jangka panjang dan bukan sebuah respons jangka pendek 


\begin{tabular}{|c|c|c|c|c|}
\hline Share: Social Work Jurnal & VOLUME: 10 & NOMOR: 1 & HALAMAN: $40-50$ & $\begin{array}{c}\text { ISSN: 2339-0042 (p) } \\
\text { ISSN: 2528-1577 }(e) \\
\text { DOI: } 10.24198 / \text { share.v10i1.26529 }\end{array}$ \\
\hline
\end{tabular}

terhadap permasalahan. Layanan sosial harus menjamin keberlangsungan serta ketahanan jangka panjang bagi setiap sasarannya;

\section{Komponen Pelayanan Sosial yang Strengths-Based}

Sebuah bentuk pelayanan sosial sekurang-kurangnya memiliki lima komponen dasar di dalamnya. Komponen-komponen tersebut antara lain tujuan dan sasaran, manfaat dan layanan, aturan kelayakan, sistem penyampaian layanan dan pembiayaan. Komponen tersebut dikembangkan sesuai dengan visi misi maupun tujuan dari layanan sosial tersebut. Untuk mempertajam sebuah layanan sosial yang Strengths-Based, berbagai komponen di atas juga harus memuat prinsip-prinsip Strengths-Perspective (Tabel 2).

Tabel 2. Kerangka Strengths-Perspective dalam Komponen Layanan Sosial

\begin{tabular}{|c|c|}
\hline $\begin{array}{l}\text { Komponen } \\
\text { Kebijakan }\end{array}$ & Indikator Strengths-Perspective \\
\hline $\begin{array}{l}\text { Tujuan dan } \\
\text { Sasaran }\end{array}$ & $\begin{array}{l}\text { - Tujuan dinyatakan secara jelas dan tidak abstrak atau umum } \\
\text { - Tujuan memuat rincian yang spesifik tentang layanan dan hasil yang } \\
\text { diharapkan } \\
\text { - Tujuan dinyatakan secara publik (tujuan manifes) } \\
\text { - Tujuan mencerminkan apa yang ingin dicapai/dapat memecahkan masalah dari } \\
\text { sasaran program } \\
\text { - Tujuan tersedia sedemikian rupa sehingga mudah diakses oleh sasaran } \\
\text { program serta masyarakat umum }\end{array}$ \\
\hline $\begin{array}{l}\text { Manfaat dan } \\
\text { Layanan }\end{array}$ & $\begin{array}{l}\text { - Manfaat dan layanan didesain untuk menghilangkan hambatan sosial yang } \\
\text { selama ini menyulitkan sasaran program untuk memenuhi kebutuhan mereka } \\
\text { - Manfaat dan layanan berfokus pada upaya memperbaiki perilaku sasaran } \\
\text { program } \\
\text { - Manfaat dan layanan telah memaksimalkan potensi, kekuatan dan sumber daya } \\
\text { - yang ada dalam diri sasaran program dan komunitasnya } \\
\text { - Manfaat dan layanan memberikan outcome yang positif bagi sasaran program }\end{array}$ \\
\hline $\begin{array}{l}\text { Aturan } \\
\text { Kelayakan }\end{array}$ & $\begin{array}{l}\text { - Aturan kelayakan dilengkapi dengan prosedur tertentu yang menghilangkan } \\
\text { stigmatisasi atau tidak menyulitkan orang yang layak untuk mengajukan diri } \\
\text { sebagai sasaran program } \\
\text { - Struktur aturan kelayakan membuka peluang selebar-lebarnya bagi sasaran } \\
\text { program untuk mengembangkan kapasitas untuk memenuhi kebutuhan } \\
\text { mereka }\end{array}$ \\
\hline $\begin{array}{l}\text { Sistem } \\
\text { Penyampaian } \\
\text { Layanan }\end{array}$ & $\begin{array}{l}\text { - Sistem penyampaian layanan didesain untuk membangun aset yang sudah ada } \\
\text { di masyarakat dan tidak membuat suatu struktur terpisah yang baru } \\
\text { - Sistem penyampaian layanan membuka berbagai macam pilihan bagi sasaran } \\
\text { program } \\
\text { - Sistem penyampaian layanan telah melibatkan SDM dari berbagai latar } \\
\text { belakang, misalnya etnis, agama, pendidikan, dan sebagainya } \\
\text { - Sistem penyampaian layanan dapat diakses oleh sasaran program dari berbagai } \\
\text { latar belakang, misalnya etnis, agama, pendidikan, dan sebagainya } \\
\text { - Sistem penyampaian layanan telah bersifat cost-effective bagi sasaran program } \\
\text { untuk mencapai hasil yang diharapkan }\end{array}$ \\
\hline Pembiayaan & $\begin{array}{l}\text { - Sumber pembiayaan menjamin stabilitas/kelangsungan program serta } \\
\text { kecukupan/ketersediaan anggaran } \\
\text { - Sistem pembayaran/reimbursement telah menjadi kelangsungan pemberi } \\
\text { layanan } \\
\text { - Sistem pembiayaan mempertimbangkan efektivitas biaya sehingga program ini } \\
\text { dapat dilanjutkan atau mungkin dikembangkan sebuah kebijakan baru dan } \\
\text { tidak dihentikan }\end{array}$ \\
\hline
\end{tabular}

Sumber: Chapin, 1995 (diolah) 


\section{Manfaat Strengths-Perspective}

Integrasi Strengths-Perspective dalam pengembangan kebijakan sosial di atas khususnya dalam layanan sosial dapat memberikan banyak manfaat. Beberapa manfaat tersebut, antara lain (Chapin, 2011):

a. Menangkal pemikiran atau paradigma yang "menyalahkan penyandang masalah" ketika terjadi masalah sosial. Melalui pendekatan ini, kita menggali kekuatankekuatan dan sumber-sumber daya yang dimiliki oleh penyandang masalah, keluarga dan lingkungan sekitar mereka. Karena berfokus pada solusi, pendekatan ini sebisa mungkin melibatkan penyandang masalah untuk memproyeksikan solusi mereka sendiri dan kemudian mengembangkan strategi untuk mencapai tujuan mereka.

b. Memberikan kesempatan kepada orangorang atau kelompok-kelompok yang selama ini aspirasi atau pandangannya kurang didengar atau bahkan diabaikan. Misalnya, kelompok yang sering mengalami diskriminasi ras, kaum perempuan, kaum gay, kaum lesbian dan penyandang disabilitas. Paradigma ini mengutamakan nilai-nilai seperti keadilan sosial, penghormatan kepada individu, serta hak akan kesamaan akses.

c. Para stakeholder kebijakan akan semakin bersemangat dan antusias untuk mendengarkan gagasan-gagasan yang muncul dari kelompok-kelompok tersebut serta bekerja sama dengan mereka untuk mencapai tujuan yang mereka harapkan. Penyusun kebijakan juga akan semakin termotivasi untuk mencari solusi atas permasalahan mereka.

Selain mengubah paradigma, implementasi Strength-Perspective juga akan menghasilkan kebijakan atau layanan sosial yang memiliki karakter berikut (Chapin, 2011):

1. Menyingkirkan hambatan-hambatan struktural yang membatasi partisipasi penuh dari penyandang masalah dalam hidup komunitas;
2. Menekankan pada akses, pilihan dan kesempatan bagi penyandang masalah yang dapat menghantar kepada pemberdayaan; dan

3. Evaluasi layanan sosial dari segi/cara pandang hasil yang diinginkan oleh penyandang masalah.

Sebuah kebijakan atau layanan sosial disebut efektif jika hasil implementasinya dapat memuaskan atau menyenangkan masyarakat, dapat menghilangkan konflik sosial serta politik dan sebagainya (Abidin, 2016). Kebijakan yang efektif juga seharusnya memberikan nilai tambah bagi setiap sasarannya seperti kemandirian (selfdetermination), keberlangsungan hidup (sustainability), keberdayaan (empowerment), ketahanan (resilience), keterlibatan (involvement/membership) dan sebagainya. Adanya Strengths-Perspective dalam pengembangan kebijakan sosial setidaknya menjamin bahwa kebijakan tersebut dapat menjawab kebutuhan sasarannya serta menyelesaikan masalahmasalah sosial yang ada.

\section{Tantangan dalam Pengembangan Kebijakan Sosial}

Sebagai sebuah kerangka berpikir yang baru dalam pengembangan kebijakan sosial, kita pasti akan menemui tantangan dalam mengimplementasikan StrengthsPerspective. Beberapa kendala yang mungkin dihadapi antara lain sebagai berikut (Hill, 2008):

1. Pelibatan berbagai stakeholder yang cukup luas dalam perencanaan dan pengembangan kebijakan dan program pemberdayaan akan memakan waktu yang cukup lama;

2. Sebuah perubahan yang fundamental mungkin akan menimbulkan penolakan karena mengubah banyak hal yang telah menjadi kebiasaan sejak lama;

3. Sebagai pendekatan yang berfokus pada perubahan yang berkelanjutan, membutuhkan waktu lama dan multigenerasi sehingga dianggap tidak efektif, 
terlalu mahal atau tidak dapat menjawab permasalahan dengan segera.

Apa yang ditawarkan oleh StrengthsPerspective adalah untuk memperkuat pendekatan-pendekatan lain yang sudah digunakan. Strengths-Perspective bukan untuk mengganti perspektif lain yang telah lama digunakan dalam pengembangan kebijakan sosial. Sebagaimana yang disampaikan Hill (2008), mari kita melihat bahwa kerangka Strengths-Perspective ini bisa menjadi salah satu metode analisis dari sekian banyak metode, dan bukan menggunakannya sebagai satu-satunya ukuran untuk menilai keberhasilan atau kegagalan sebuah kebijakan atau layanan sosial.

\section{SIMPULAN}

Kajian menunjukkan bahwa Strengths-Perspective dapat menjadi salah satu perspektif dalam pengembangan kebijakan sosial khususnya dalam memperkuat pengembangan layanan sosial. Pelayanan sosial yang berdasarkan evaluasi kurang memberikan kontribusi positif bagi sasarannya sudah seharusnya diperkuat melalui Strengths-Perspective. Pendekatan ini tidak menyepelekan masalah yang terjadi tapi juga tidak berhenti pada upaya mengatasi masalah. Pendekatan ini dapat menjamin bahwa pelayanan sosial yang disusun telah sesuai dengan apa yang diharapkan oleh target sasarannya. Tujuan layanan sosial menggambarkan tujuan yang ingin dicapai oleh target sasarannya.

Pelayanan sosial baik dalam bentuk jaminan sosial, pelayanan perumahan, kesehatan, pendidikan, serta pelayanan personal harus memberikan output yang jelas dan terukur kepada setiap sasarannya. Oleh karena ini, upaya ini dapat memberikan masukan bagi para praktisi kebijakan berupa instrumen yang bisa digunakan untuk mengkonseptualisasikan kebutuhan dan permasalahan sosial dalam rangka menyusun sebuah layanan sosial yang lebih baik. Pendekatan ini juga dapat menjadi sebuah pendekatan yang lebih inklusif bagi perumusan kebijakan serta memperkaya opsiopsi kebijakan (Chapin, 1995).

Output dari pendekatan ini dalam pengembangan kebijakan sosial atau layanan sosial seperti melibatkan setiap target sasarannya dalam perumusannya. Pendekatan ini juga memberikan pilihan yang seluas-luasnya bagi target sasaran dimana pilihan yang tersedia bagi mereka sungguhsungguh dapat dijalankan dan memberikan hasil yang maksimal bagi sasarannya. Hal yang tidak kalah penting adalah keyakinan bahwa sebuah layanan sosial yang terbentuk mampu menjamin terwujudnya kemandirian, ketahanan, keberdayaan, keberlanjutan, kesetaraan serta keadilan sosial bagi setiap penerima layanan tersebut.

\section{DAFTAR PUSTAKA}

Abidin, S. Z. (2016). Kebijakan Publik (3rd ed.). Salemba Humanika.

Birkland, T. A. (2011). An Introduction to the Policy Process: Theories, Concepts, and Models of Public Policy Making (3rd ed.). Routledge.

Brueggemann, W. G. (2014). The Practice of Macro Social Work (4th ed.). Brooks/Cole.

Chapin, R. K. (1995). Social Policy Development: The Strengths Perspective. Social Work, 40(4), 506514. https://doi.org/10.1093/sw/40.4.506

Chapin, R. K. (2011). Social Policy for Effective Practice: A Strengths Approach (2nd ed.). Routledge.

Dunn, W. N. (2018). Public Policy Analysis (3rd ed.). Routledge.

Guo, W., \& Tsui, M. (2010). From resilience to resistance: A reconstruction of the strengths perspective in social work practice. International Social Work, 53(2), 233-245. https://doi.org/10.1177/00208728093 55391

Hill, K. (2008). A Strengths-Based Framework 


\begin{tabular}{|c|c|c|c|c|}
\hline Share: Social Work Jurnal & VOLUME: 10 & NOMOR: 1 & HALAMAN: $40-50$ & $\begin{array}{c}\text { ISSN: 2339-0042 (p) } \\
\text { ISSN: } 2528-1577(e) \\
\text { DOI: } 10.24198 / \text { share.v10i1.26529 }\end{array}$ \\
\hline
\end{tabular}

for Social Policy: Barriers and Possibilities. Journal of Policy Practice, त2-3), 106-121. https://doi.org/10.1080/15588740801 937920

Ishartono, I., \& Raharjo, S. T. (2016). Perspektif Kekuatan dalam Pekerjaan Sosial. EMPATI: Jurnal IImu Kesejahteraan Sosial, 5(1), 1-10. https://doi.org/10.15408/empati.v5i1. 9772

Midgley, J, Tracy, M. B., \& Livermore, M. (2000). The Handbook of Social Policy. SAGE Publication.

Midgley, James, \& Livermore, M. (2009). The handbook of Social Policy (2nd ed.). SAGE Publication.

Netting, F. E., Kettner, P. M., McMurtry, S. L., \& Thomas, M. L. (2017). Social Work Macro Practice (6th ed.). Pearson.

Nugroho, R. (2014). Kebijakan Sosial untuk Negara Berkembang. Pustaka Pelajar.

Rapp, C. A., Pettus, C. A., \& Goscha, R. J. (2006). Principles of Strengths-Based Policy. Journal of Policy Practice, 5(4), 3-18.

https://doi.org/10.1300/J508v05n04_ 02
Saleebey, D. (1995). The strengths perspective in social work practice. Social Work (United States), 40(2), 280-281. https://doi.org/10.1093/sw/40.2.280

Saleebey, D. (2000). Power in The People: Strengths and Hope. Social Work, 1(2), 127-136.

Spicker, P. (2014). Social Policy: Theory and Practice. Policy Press.

Suharto, E. (2012). Analisis Kebijakan Publik: Panduan Praktis Mengkaji dan Masalah dan Kebijakan Sosial. Alfabeta.

Walsh, M., Stephens, P., \& Moore, S. (2000). Social Policy and Welfare. Stanley Thornes.

Zastrow, C., \& Kirst-Ashman, K. K. (2007). Understanding Human Behavior and the Social Environment (7th ed.). Brooks/Cole. 